\title{
Study on the Weldability of AA2519 Armor Grade Aluminium Alloy
}

Robert Kosturek (0000-0002-6663-0529), Lucjan Śnieżek (0000-0002-1157-0565), Krzysztof Grzelak (0000-00030675-1983), Janusz Torzewski (0000-0001-6475-9997)

Department of Fatigue and Machine Design, Faculty of Mechanical Engineering, Military University of Technology, gen. Sylwestra Kaliskiego 2 St., 00-908 Warsaw, Republic of Poland. E-mail: robert.kosturek@wat.edu.pl

This paper describes series of studies concerned with welding of Sc-modified AA2519 at the Military University of Technology. The modification of AA2519 alloy contains a higher concentration of scandium and zirconium and it has been developed in The Institute of Non Ferrous Metals, Light Metals Division in Skawina. The examination involves friction stir welding (FSW) and laser beam welding (LBW) of 5 $\mathrm{mm}$ thick AA2519-T62 extrusion. FSW process parameters were: $600 \mathrm{rpm}$ tool rotation speed, 100 $\mathrm{mm} / \mathrm{min}$ welding velocity, $4.8 \mathrm{~mm}$ depth plunge, and MX Triflute tool type. The used LBW parameters were as follows: $3.2 \mathrm{~kW}$ laser power, $1.1 \mathrm{~m} / \mathrm{min}$ welding velocity, $0.2 \mathrm{~mm}$ laser beam width, $10^{\circ}$ laser beam inclination angle, $10 \mathrm{~L} / \mathrm{min}$ shielding gas (argon) flow with the laser beam focused on the workpiece surface $(\mathrm{f}=\mathbf{0})$. In this work selected results have been presented containing some problems and features typical for investigated joints. Butt joints produced by FSW and LBW have been compared in terms of microstructure (grains), microhardness distribution, joint efficiency, localization of failure, etc. The basic features of weld zones have been discussed together with the distributions of microhardness on the joint's cross-sections. Both welding techniques cause a reduction of microhardness in the weld zone, but the drop from the base material's value (135-140 HV0.1) is far higher in the case of LBW (85-90 HV0.1) than FSW (120 HV0.1). The established values of joint efficiency were $80 \%(376 \mathrm{MPa})$ and $66 \%(314 \mathrm{MPa})$ for FSW and LBW, respectively. The FSW joints tend to fail in the thermo-mechanically affected zone and LBW in the fusion zone.

Keywords: AA2519, aluminium, laser beam welding, friction stir welding, mechanical properties

\section{Introduction}

AA2519 is an aluminium alloy with application in the construction of military vehicles thanks to its high specific strength and good ballistic resistance [1]. The recent, polish, modification of this material developed in The Institute of Non Ferrous Metals, Light Metals Division in Skawina contains a higher concentration of scandium and zirconium. These additions cause grain refinement (during solidification - casting or welding), increase in strength (due to presence of nanoprecipitates), and increase in temperature of recrystallization and grain growth (by pining of grain boundaries) [2-3]. This version of the alloy is the subject of series of investigations at the Military University of Technology (MUT) including explosive welding [4] and post-processing [5], friction stir welding [6-8], and laser beam welding. The joining of AA2519 causes some problems including two major ones of metallurgical and of technical nature. The high concentration of copper in AA2519 makes welded joints very susceptible to hot cracking during the solidification of a fusion zone. Additionally, considering welding of a material used in military vehicles we have to pay attention to the behaviour of a weld during being hit by a projectile, and in this case, welded joints produced by conventional means (e.g. by Tungsten Inert Gas) with cast-ingot structure tend to fragment in such extreme condition [9-11]. For manufacturing of a butt-joint of an aluminium alloy, the method of friction stir welding gives the best effects in terms of mechanical properties, due to the solid-state nature of the process and the formation of ultrafine grain microstructure in the stir zone $[7,12]$. FSW allows to obtain a relatively high joint efficiency for precipitation-hardened aluminium alloys of $70-90 \%$ with no defects typical for conventional welding processes such as solidification cracks and pores [13]. This technique has its limits and the production of welds of sophisticated shapes can sometimes be problematic. Another technique, which can be a solution for some problems with welding AA2519 is laser beam welding. Despite the fact that a welded joint has a cast-ingot macrostructure, the width of joints is relatively low (comparing to conventional techniques) and more complex shapes of a welded structure are easily possible to manufacture. Whichever technique would be chosen to weld AA2519, we have to take under consideration losses of the strengthening phase $\theta^{\prime}$ (formed in the precipitation hardening process), what entails a noticeably decrease in mechanical properties, possible to identify e.g. in the reduction of microhardness in the joint zone [14]. 
In this investigation, the aim is to compare the basic properties of AA2519-T62 welded butt joints obtained by FSW and LBW in terms of macro and microstructure, microhardness distribution, joint efficiency, and failure localization.

\section{Materials and Methods}

The subject of the investigation was $5 \mathrm{~mm}$ thick AA2519-T62 extrusion with the chemical composition and presented below in tables 1-2.

Tab. 1 Chemical composition of A A2519-T62 extrusion.

\begin{tabular}{|c|c|c|c|c|c|c|c|c|c|c|c|}
\hline $\mathrm{Fe}$ & $\mathrm{Si}$ & $\mathrm{Cu}$ & $\mathrm{Zn}$ & $\mathrm{Ti}$ & $\mathrm{Mn}$ & $\mathrm{Mg}$ & $\mathrm{Ni}$ & $\mathrm{Zr}$ & $\mathrm{Sc}$ & $\mathrm{V}$ & $\mathrm{Al}$ \\
\hline 0.11 & 0.08 & 6.32 & 0.05 & 0.08 & 0.17 & 0.33 & 0.02 & 0.19 & 0.16 & 0.10 & Base \\
\hline
\end{tabular}

Tab. 2Mechanical properties of AA2519-T62 extrusion.

\begin{tabular}{|c|c|c|c|}
\hline Yield Strength, $\mathrm{R}_{0,2}$ & Tensile Strength, $\mathrm{R}_{\mathrm{m}}$ & Fracture Stress, $\mathrm{R}_{\mathrm{u}}$ & Elongation, A \\
\hline $320 \mathrm{MPa}$ & $474 \mathrm{MPa}$ & $443 \mathrm{MPa}$ & $19 \%$ \\
\hline
\end{tabular}

Before the welding, the surfaces of workpieces have been ground and cleaned with isopropyl alcohol. The welding processes have been conducted on the workpieces with the size of $80 \times 250 \mathrm{~mm}$, using ESAB Legio 4UT (FSW) and Fanuc 710i industrial robot equipped with YLS-6000 $6 \mathrm{~kW}$ laser beam source (LBW). FSW process parameters were: $600 \mathrm{rpm}$ tool rotation speed, $100 \mathrm{~mm} / \mathrm{min}$ welding velocity, $4.8 \mathrm{~mm}$ depth plunge, and MX Triflute tool type. The used LBW parameters were as follows: $3.2 \mathrm{~kW}$ laser power, $1.1 \mathrm{~m} / \mathrm{min}$ welding velocity, $0.2 \mathrm{~mm}$ laser beam width, $10^{\circ}$ laser beam inclination angle, $10 \mathrm{~L} / \mathrm{min}$ shielding gas (argon) flow with the laser beam focused on the workpiece surface $(\mathrm{f}=0)$. After the welding processes, samples have been cut in the direction perpendicular to the welding direction. The cut samples were mounted in hot-mounting resin, ground with abrasive paper of $80,320,600,1200,2400,4000$ gradations, and polished using a diamond paste of $3 \mu \mathrm{m}$ and $1 \mu \mathrm{m}$ gradation. An important feature in friction stir welded joints is the asymmetry of a welded zone, and we can distinguish the advancing side (the direction of the tool rotation is accordant with the welding direction) and the retreating side (the direction of the tool rotation is opposite to the welding direction). The macrostructure has been revealed using Keller's reagent consisting of $20 \mathrm{~mL} \mathrm{H}_{2} \mathrm{O}, 5 \mathrm{~mL} 63 \% \mathrm{HNO}_{3}, 1 \mathrm{~mL}$ $40 \% \mathrm{HF}$, and one drop of $36 \% \mathrm{HCl}$. The analysis was supported by Vickers microhardness distribution using $0.98 \mathrm{~N}$ load. The tensile test was carried out on INSTRON 8802 MTL equipped with WaveMatrix software. The scheme of the sample for the tensile test is presented below (Fig. 1).

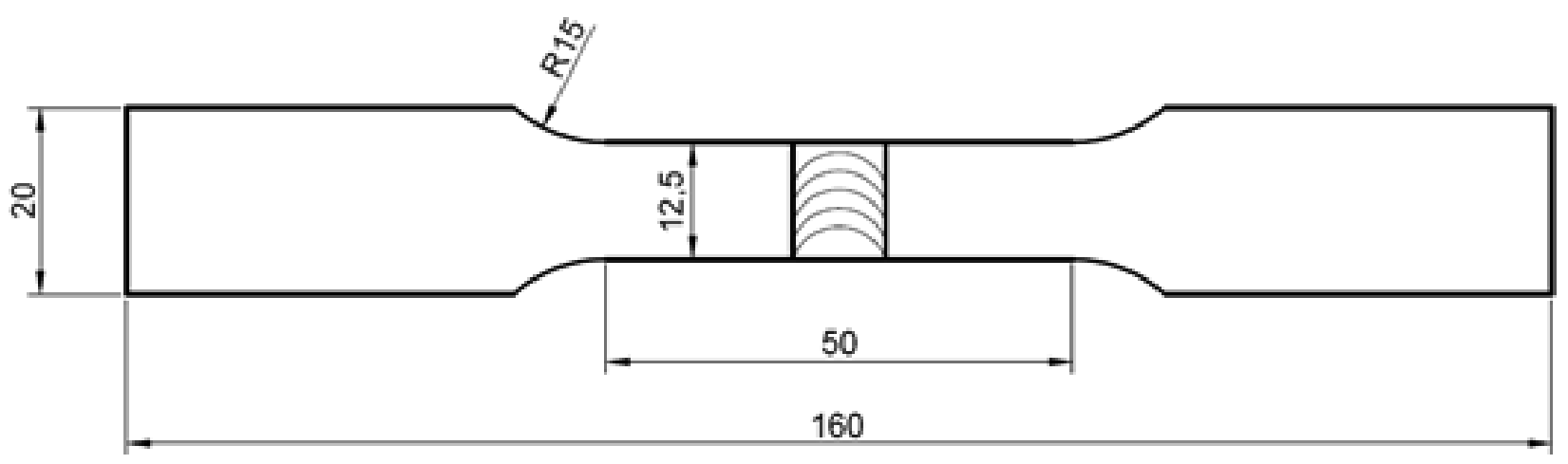

Fig. 1 The scheme of the sample for the tensile test.

The scheme of the welded joint is only to illustrate the localization of a joint in the sample and the real widths of the joints are different. The fractography analysis has been conducted on scanning electron microscope Jeol JSM-6610.

\section{Results and Discussion}

The macrostructures of obtained joints are presented in Fig. 2a-b. The sample obtained by laser beam welding (Fig. 2a) has a typical structure of cast-ingot with the width of the fusion zone of about $5.5 \mathrm{~mm}$ (weld face) and $2.3 \mathrm{~mm}$ (weld throat). The macroscopic observations did not reveal the presence of solidification cracks, but in the central part of the fusion zone, the porosity is possible to observe. On the other hand, the joint obtained in the friction stir welding process (Fig. 2b) has a noticeable number of superiorities e.g. fine-grained macrostructure of the stir zone, no defects (pores, cracks, voids), and insignificant reduction of workpiece thickness in the weld. The part of the material removed from the stirring zone forms the flash, which can be observed on the retreating side 
of the FSW joint. The width of the stir zone is about $9 \mathrm{~mm}$. The real area of the material affected by a welding process is more suitable to identify in microhard- ness distribution. The results of microhardness analysis on the distance of $2.5 \mathrm{~mm}$ from the bottom of the joints is presented are Fig. 3.
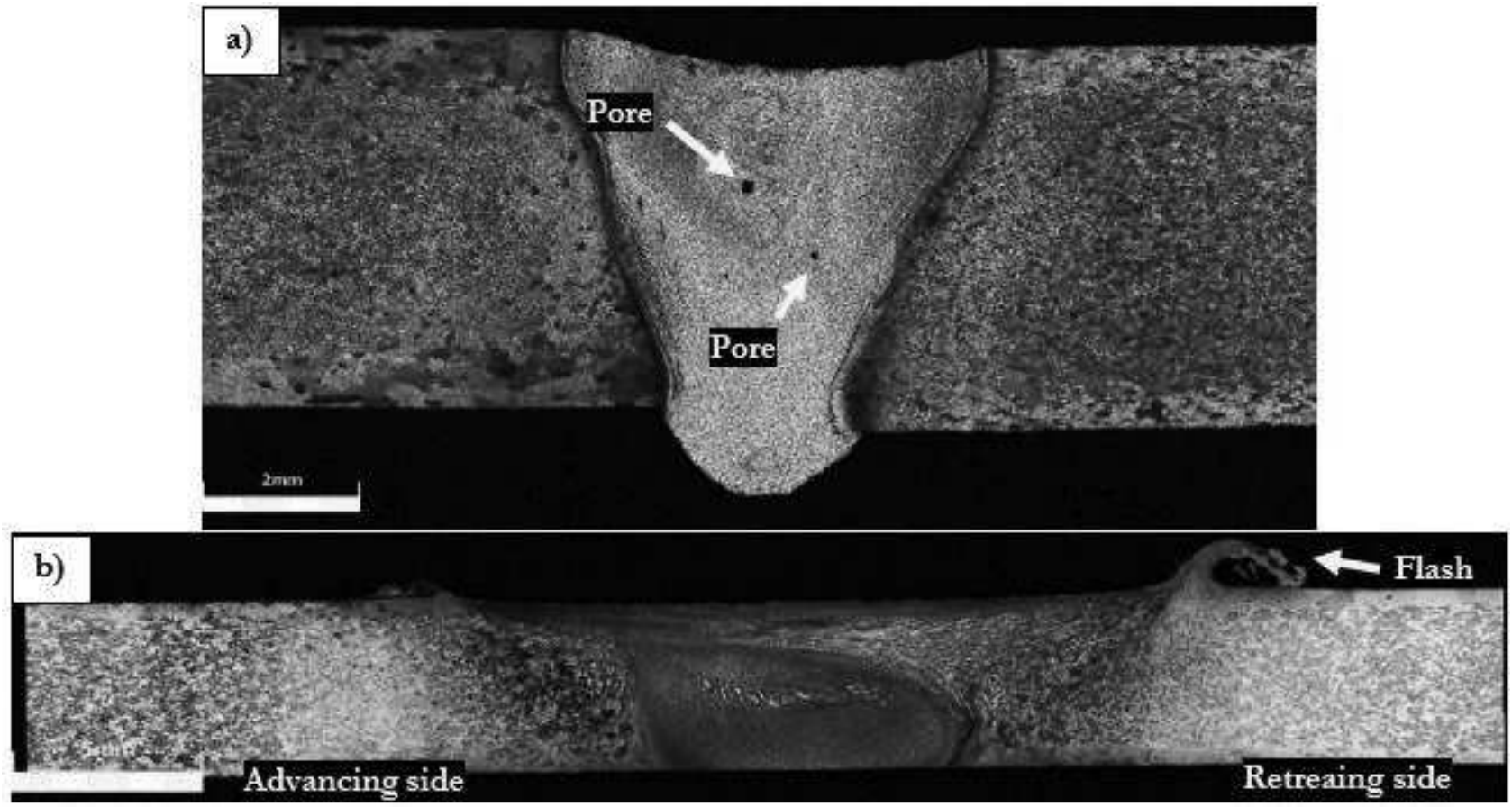

Fig. 2 The macrostructure images of a) laser beam welded b) friction stir welded joint of AA2519-T62.

The obtained microhardness distributions allow to estimate the influence of the welding processes. Both welding techniques cause a reduction of microhardness in the weld zone, but the drop from the base material's value (135-140 HV0.1) is far higher in the case of LBW (85-90 HV0.1) than FSW (120 HV0.1). It is connected with the phenomenon of an overaging of the strengthening phase due to the temperature of the processes (around $400-450^{\circ} \mathrm{C}$ for $\mathrm{FSW}$, and above the melting point $\left[660^{\circ} \mathrm{C}\right]$ for $\left.\mathrm{LBW}\right)$. The overaging brings the value of microhardness to around 80-85 HV0.1,

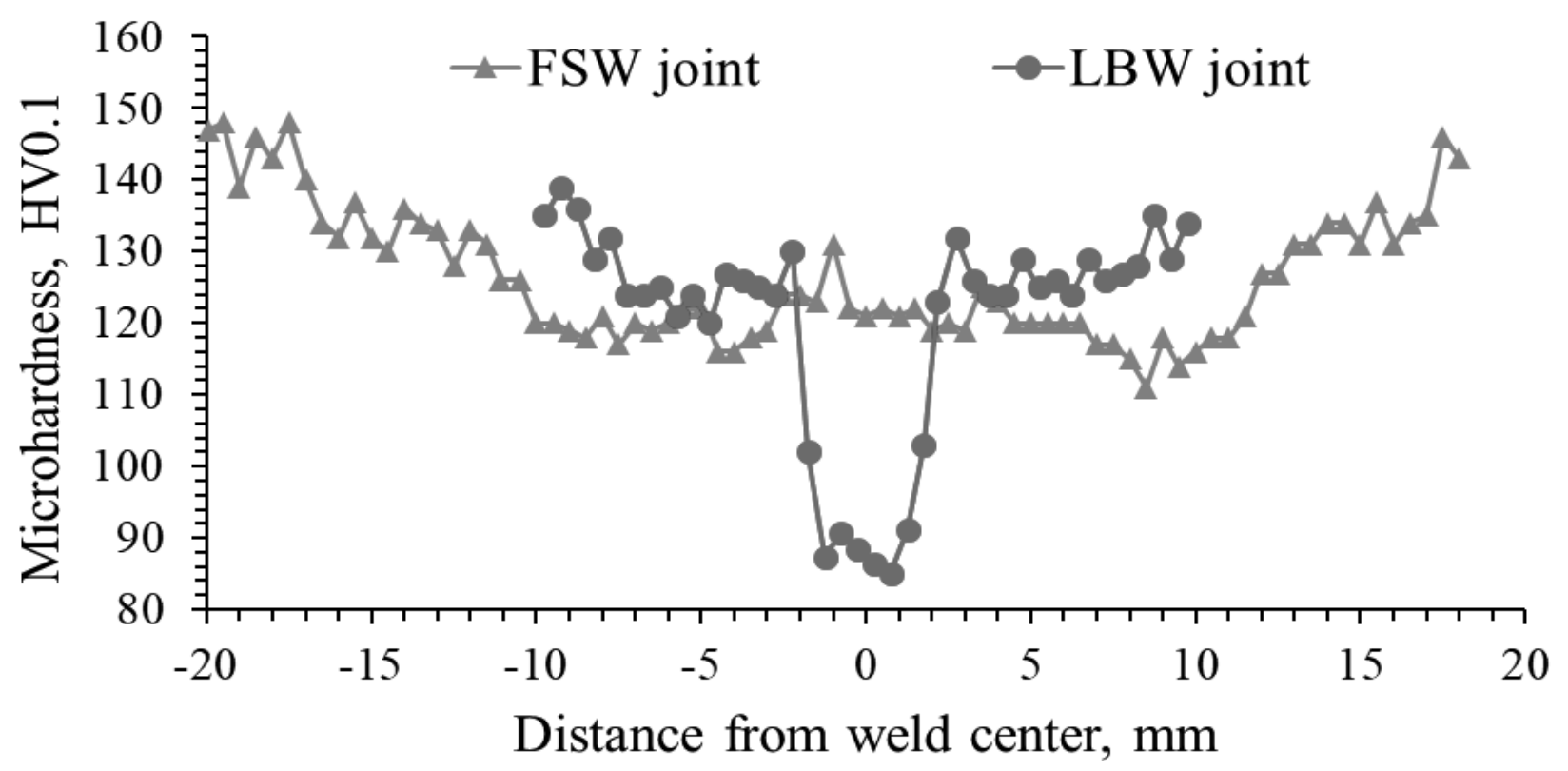

Fig. 3 The microhardness distribution of the welded joints cross-sections.

what corresponds to the value for annealed AA2519. This is mostly visible in the LBW joint, which is characterized by higher heat input, although it is very local. In the case of FSW, despite the fact of the overaging, the microhardness value is partly compensated by significant grain refinement in the stir zone and grains deformation in the thermo-mechanically affected zone (resulting in grain-boundary strengthening). The FSW joint has its lowest microhardness in the heataffected zone at the retreating side (characterized by higher heat input) - about 110 HV0.1. 
The width of the LBW joint's fusion zone at the analyzed distance is about $4.5 \mathrm{~mm}$ and the FSW stir zone is two times wider ( $9 \mathrm{~mm})$. Summarizing, the FSW affects a larger amount of the workpiece's mate-
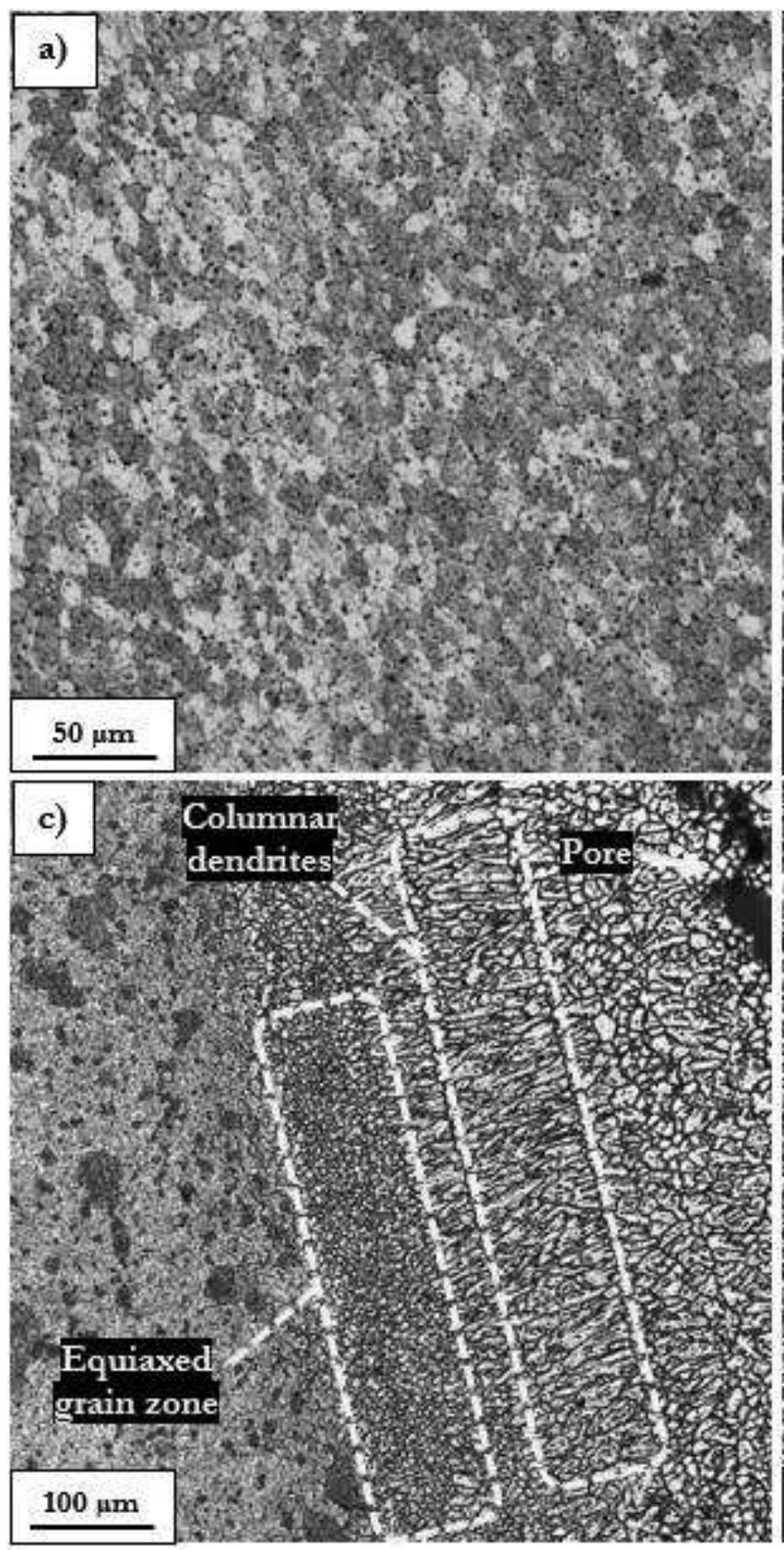

rial, but it causes a spreaded, low reduction of microhardness in opposite to a very high, localized drop of this value for LBW. The welding processes also form a completely different microstructure with some typical features (Fig. 4a-c).
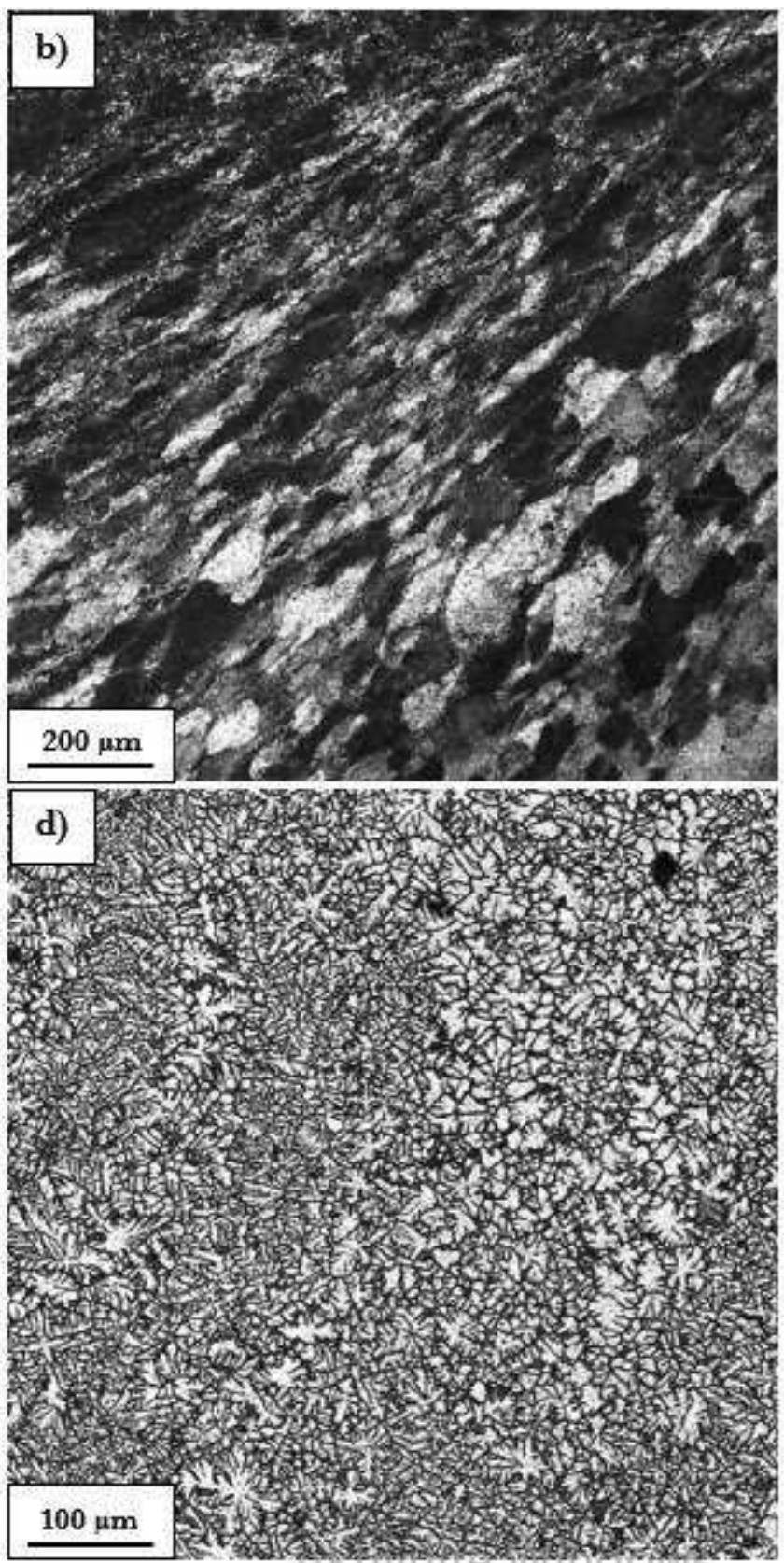

Fig. 4 The microstructure images of a) the stir zone, b) the thermo-mechanically affected zone (retreating side), c) the fusion line area, d) the fusion zone center.

In the stir zone (Fig. 4a), it is possible to observe a typical for FSW process ultrafine, dynamically recrystallized microstructure - the result of severe plastic deformation in high temperature. The microstructure is homogenous, with the average size of grain about 10 $\mu \mathrm{m}$. On the contrary, the thermo-mechanically affected zone (Fig. 4b), which also has been subjected to hot deformation during the welding process did not undergo dynamic recrystallization and the deformed grains reflect the flow of the material in the stirring process. At the same time, in the LBW sample, the area close to the fusion zone besides having the castingot structure, has some features typical for an aluminum alloy modified with scandium (Fig. 4c). The equiaxed grain zone crystallized directly from the fusion line has a fine-grained microstructure with a grain size of $10 \mu \mathrm{m}$ and below. The references and research conducted at MUT connect the formation of this ultrafine 
zone with the participation of scandium in the alloy composition [13,14]. Moving in a direction of the weld's centrum, the columnar dendrites can be observed, oriented parallel to the heat flow. In this area occurs a sporadic porosity of solidification shrinkage origin (Fig. 4c). The fusion zone center has a microstructure consisting of equiaxed dendrites (Fig. 4d) with small differences in size and shape.

The results of the conducted tensile test allow to fully evaluate joints qualities. The comparison of obtained welded joints to the base material is presented below on representative samples (Fig. 5).

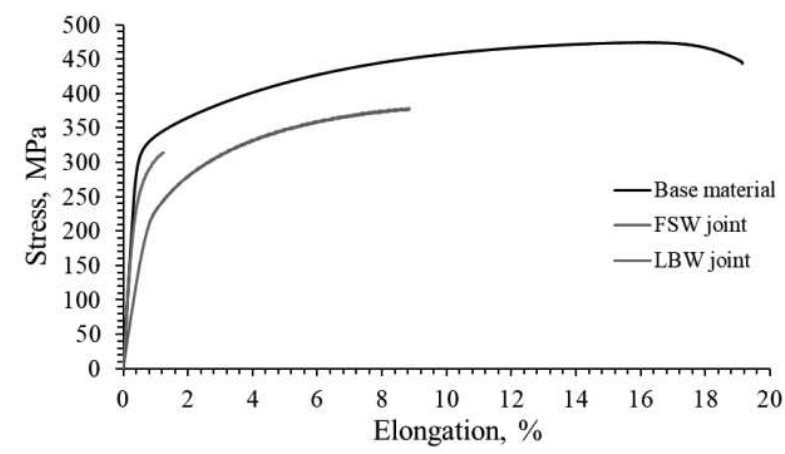

Fig. 5 The comparison of the base material (AA2519-T62) and the welded joint tensile curves.
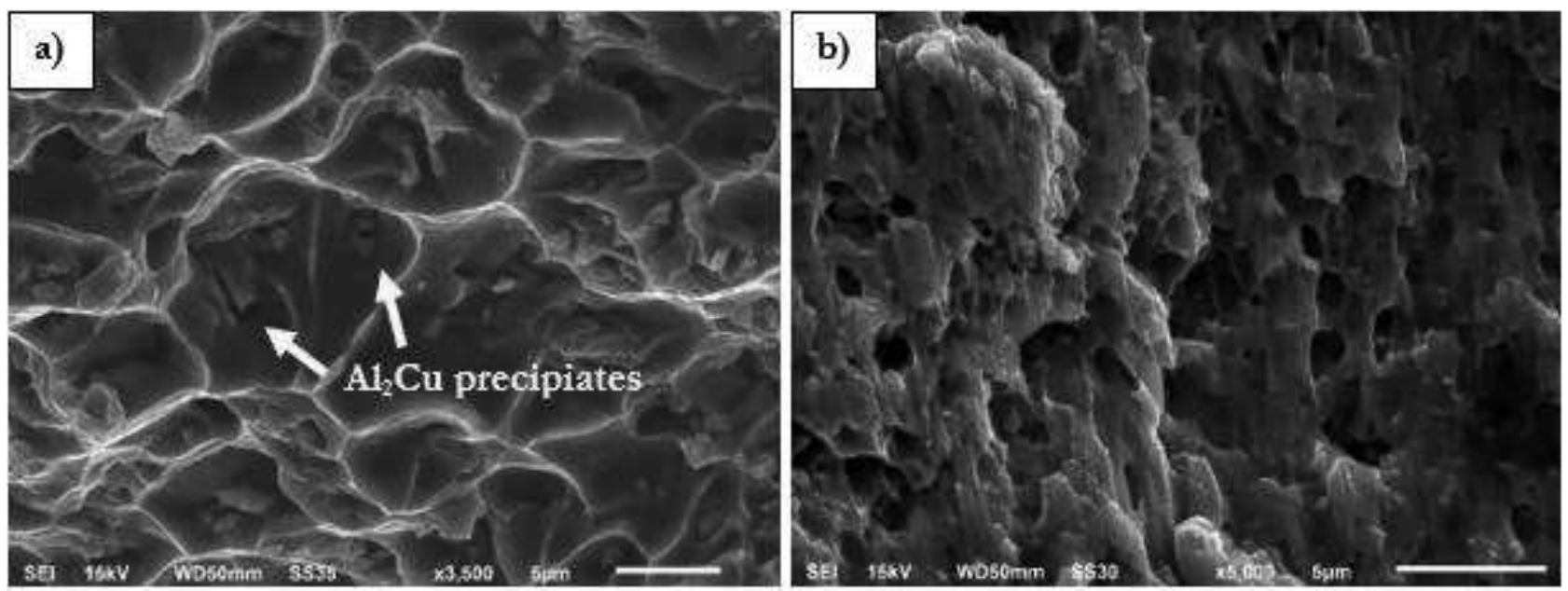

The established values of joint efficiency are $80 \%$ $(376 \mathrm{MPa})$ and $66 \%(314 \mathrm{MPa})$ for FSW and LBW, respectively. The failure of the LBW joint occurred in the fusion zone, being identified as the softest region of the joint (Fig. 2,3). For the FSW joints, a tendency to fail in the thermo-mechanically affected zone has been reported, in some cases with participation of decohesion on the interface of the stir and thermo-mechanically affected zones on the advancing side of the welds. The welding processes caused a reduction in elongation to break, from the value of the base material of $19 \%$, in the conducted tensile tests it reaches $9 \%$ for FSW and slightly above 1\% for LBW. Although it seems that the FSW joint has nine times higher elongation than the LBW joint, it has to be taken under consideration fact that both welded joints are tested with the same tensile geometry (Fig. 1). So, the value of elongation always referring to the extensometer base of $50 \mathrm{~mm}$ and on this length, the LBW joint takes only about $10 \%$. During the testing, immediately after the elastic deformation of a sample reaches its limits, the plastic deformation strongly accumulates in the fusion zone of the LBW joint, what finds its reflection in the fractography analysis (Fig. 6a-b).

Fig. 6 SEM images of selected parts of fracture surfaces for a) $L B W$ joint, b) FSW joint.

The LBW joint's fracture surface is characterized by a typical dimple structure with visible $\mathrm{Al}_{2} \mathrm{Cu}$ precipitates and the failure itself is of ductile nature. In the FSW sample, the dimples are smaller and the participation of brittle fracture seems to be slightly higher.

\section{Conclusions}

The performed investigation allowed for the basic comparison of FSW and LBW in terms of AA2519 weldability. Both techniques can be used for manufacturing butt joints with acceptable quality. The only reported imperfections refer to the LBW joint in a form of gas porosity (macroscopic level) and shrin- 
joint takes place in the thermo-mechanically affected zone (sometimes with the participation of the stir zone interface) at the advancing side. The failure in the $\mathrm{LBW}$ joint is dictated by its weakest zone - a very soft, overaged, casted fusion zone, which fractures with the formation of typical dimple structures.

\section{Acknowledgement}

This research was funded by Polish Ministry of National Defence grant number: PBG/13-998

\section{References}

[1] FISHER, J., JAMES, J. (2002). Aluminum alloy 2519 in military vehicles, Materials Science Forum, 160, pp. 43-46.

[2] TAENDL, J., POLETTI, C. (2016). Influence of $\mathrm{Al} 3(\mathrm{Sc}, \mathrm{Zr})$ Precipitates on Deformability and Friction Stir Welding Behavior of Al-MgSc-Zr Alloys, BHM Berg- und Hüttenmännische Monatshefte, 161(7), pp. 330-333.

[3] SAUVAGE, X., DEDE, A., CABELlO MUNOZ, A., HUNEAU, B. (2008). Precipitate stability and recrystallisation in the weld nuggets of friction stir welded $\mathrm{Al}-\mathrm{Mg}-\mathrm{Si}$ and $\mathrm{Al}-\mathrm{Mg}-\mathrm{Sc}$ alloys, Materials Science and Engineering A, 491(1-2), pp. 364-371.

[4] WACHOWSKI, M., KOSTUREK, R., ŚNIEŻEK, L., MRÓZ, S., GLOC, M., KRAWCZYŃSKA, A., MAŁEK, M. (2019). Analysis of the microstructure of an AZ31/AA1050/AA2519 laminate produced using the explosive-welding method, Materiali in Tehnologije, 53(2), pp. 239-243.

[5] WACHOWSKI, M., KOSTUREK, R., ŚNIEŻEK, L., MRÓZ, S., STEFANIK, A., SZOTA, P. (2020). The Effect of Post-Weld Hot-Rolling on the Properties of Explosively Welded Mg/Al/Ti Multilayer Composite, Materials, 13(8), pp. 1-15.

[6] KOSTUREK, R., ŚNIEŻEK, L., TORZEWSKI, J., WACHOWSKI, M. (2002). The influence of welding parameters on macrostructure and mechani-cal properties of Scmodified AA2519-T62 FSW joints, Manufacturing Review, 7(28), pp. 1-9.

[7] KOSTUREK, R., ŚNIEŻEK, L., TORZEWSKI, J., WACHOWSKI, M. (2019). Research on the Friction Stir Welding of Scmodified AA2519 extrusion, Metals - Open Access Metallurgy Journal, 9(10), pp. 1-15.
[8] KOSTUREK, R., ŚNIEŻEK, L., TORZEWSKI, J., ŚLĘZAK, T., WACHOWSKI, M., SZACHOGLUCHOWICZ, I. (2020). Research on the properties and low cycle fatigue of Sc-modified AS2519-T62 FSW joint, Materials, 13(22), pp. 1-18.

[9] BALAKRISHNAN, M., BALASUBRAMANIAN, V., MADHUSUDHAN REDDY, G. (2013). Microstructural Analysis of Ballistic Tests on Welded Armor Steel Joints, Metallography Microstructure and Analysis, 2(3), pp. 125-139.

[10] NOVAKOVA, I., MORAVEC, J., SVEC, M., KIK, T., KORECEK, D. (2019). Influence of the Welding Process on the Change of Mechanical Properties in the HAZ of Welds at Alloy AW 6005 and Possibilities of Their Renewal by Heat Treatment, Manufacturing Tecbnology, 19(5), pp. 823-830.

[11] ALBANNAI, A., ALORAIER, A., ALASKARI, A., ALAWADHI, M., JOSHI, S. (2021). Effects of tandem side-by-side GTAW welds on centerline solidification cracking of AA2024, Manufacturing Technology, 21(2), pp. 151-163.

[12] TORZEWSKI, J., GRZELAK, K., WACHOWSKI, M., KOSTUREK, R. (2020). Microstructure and low cycle fatigue properties of AA5083 H111 friction stir welded joint, $M a$ terials, 13(10), pp. 1-14.

[13] ÇAM, G., MISTIKOGLU, S. (2014). Recent Developments in Friction Stir Welding of Alalloys, Journal of Materials Engineering and Performance, 23(6), pp. 1936-1953.

[14] LIANG, X.P., LI, H.Z., LI, Z., HONG, T., MA, B., LIU, S.D., LIU, Y. (2012). Study on the microstructure in a friction stir welded 2519 T87 Al alloy, Materials and Design, 35, pp. 603608.

[15] SMOLEJ, A., MARKOLI, B., NAGODE, A., KLOBČAR, D. (2015). Influence of minor scandium and zirconium additions on the microstructure of $\mathrm{Al}$ and $\mathrm{Al}-5 \mathrm{Mg}$ alloy, $\mathrm{RMZ}$ materials and geoenvironment, 62(2), pp. 73-80.

[16] KASHAEV, N., VENTZKE, V., ÇAM, G. (2018). Prospects of laser beam welding and friction stir welding processes for aluminum airframe structural applications, Journal of Manufacturing Processes, 36, pp. 571-600. 